\title{
Retrospective analysis of the patients with brain death diagnosis in the last five years in our hospital
}

\section{Hastanemizde son 5 yıl içerisinde beyin ölüimü tanısı alan olguların retrospektif analizi}

\author{
Onur Avci ${ }^{1}$, Oğuz Güindloğdu²
}

${ }^{1}$ Cumhuriyet University Faculty of Medicine Department of Anesthesiology and Reanimation, Sivas, Turkey

${ }^{2}$ Numune Hospital Department of Anesthesiology, Sivas, Turkey

Corresponding author: Onur Avc1, MD, Cumhuriyet University Faculty of Medicine Department of Anesthesiology and Reanimation, Sivas, Turkey

E-mail: dronuravci@gmail.com

Received/Accepted: June 10, 2019 /June 17, 2019

Conflict of interest: There is not a conflict of interest.

\section{SUMMARY}

Objective: This study aims to investigate the organ donation rate, the causes of brain death and the blood gas parameters before and after apnea test by assessing the records of the patients with brain death diagnosis in the last five years in our hospital.

Method: The records of 44 patients who were diagnosed as brain death between 01.01.2014-15.05.2019 at Cumhuriyet University Research and Application Hospital were retrospectively reviewed. Blood gas parameters before and after apnea test, demographic characteristics, educational status, duration of diagnosing brain death, distribution of the patients according to their services, organ donation rate, the causes of brain death were evaluated. Results: When the patients diagnosed with brain death in Cumhuriyet University Hospital between January 2014 and May 2019, 44 patients were found. Of these patients, 23 were female $(52.3 \%)$ and 21 were male $(47.7 \%)$. When the patients who were diagnosed with brain death were examined; 26 patients $(59.1 \%)$ were found to be in the neurosurgery intensive care unit and 13 patients $(29.5 \%)$ in anesthesia intensive care unit. When the causes leading to brain death are examined; The most common cause was subarachnoid hemorrhage $(\mathrm{SAH})$ in 18 patients $(40.9 \%)$. Of the 44 patients diagnosed with brain death, $9(20.5 \%)$ were donors, and $35(79.5 \%)$ were not donors.

Conclusions: This retrospective evaluation of 44 patients diagnosed with brain death within five years in intensive care units of our hospital revealed that organ donation rates were below the national average. We think that not delaying in donor determination, not to be lack of donor care, training of health workers in brain death and organ donation will increase the awareness on organ donation and organ donation rates will increase in our hospital.

Keywords: Brain death, apnea test, organ donor, intensive care
Onur Avc1

Oğuz Gündoğdu

ORCID IDs of the authors: O.A. 0000-0003-0743-754X O.G. 0000-0002-8864-0015 
Amaç: Bu çalışmada; hastanemizde son 5 yıl içerisinde beyin ölümü tanısı konulmuş olguların kayıtları incelenerek organ bağış oranları, beyin ölümü nedenleri ile apne testi öncesi ve sonrasındaki kan gazı parametrelerinin araştırılması amaçlanmıştır.

Yöntem: Cumhuriyet Üniversitesi Araștırma ve Uygulama Hastanesi’nde 01.01.2014-15.05.2019 tarihleri arasında beyin ölümü tanısı almış 44 olgunun kayıtları retrospektif olarak incelendi. Olguların demografik özellikleri, eğitim durumları, beyin ölümü tanı süreleri, beyin ölümü tanısı alan olguların yattığı servislere göre dağılımları, organ bağış oranları, beyin ölümü nedenleri ile beyin ölümü tanısı için uygulanan testlerden apne testi öncesi ve sonrasındaki kan gazı parametreleri incelendi.

Bulgular: Ocak 2014-Mayıs 2019 tarihleri arasında Cumhuriyet Üniversitesi Hastanesi'nde beyin ölümü tanısı alan hastalar incelendiğinde toplam 44 hasta mevcuttu. Bu hastaların 23'ü kadın (\%52.3), 21'i erkek (\%47.7) idi. Beyin ölümü tanısı alan hastaların yattı̆̆ı servisler incelendiğinde; 26 hastanın (\%59.1) beyin cerrahisi yoğun bakımda, 13 hastanın ise (\%29.5) anestezi yoğun bakımda yattığı tespit edildi. Beyin ölümüne yol açan nedenler incelendiğinde; en sık neden olarak subaraknoid kanama (SAK) 18 hastada (\%40.9) olduğu görüldü. Beyin ölümü tanısı konulan 44 hastadan 9 hasta (\%20.5) donör olurken, 35 hasta (\%79.5) donör olmamışıtır.

Sonuç: Hastanemiz yoğun bakımlarında 5 yıl içinde beyin ölümü tanısı konan 44 olgunun retrospektif değerlendirilmesi sonucunda organ donasyon oranlarının ülke ortalamasının altında olduğu saptanmıştır. Donör tespitinde gecikilmemesi, donör bakımında yetersiz kalınmaması, sağlık çalışanlarının beyin ölümü ve organ bağışı konusunda eğitilmesi ve organ bă̆ı̧̧ konusunda farkındalıkların artııılması ile organ bağı̧ıı oranlarının hastanemizde daha da artacă̆ını düşünmekteyiz.

Anahtar sözcü̈kler: Beyin ölümü, apne testi, organ donörü, yoğun bakım

\section{INTRODUCTION}

Brain death diagnosis is inevitable in intensive care practice, and it is necessary to approach with sensitivity to the close relatives the patients by considering the awareness of the possibility of organ donation. When the possibility of brain death increases, it is necessary to have an honest discussion with the family members. The declaration of brain death requires the demonstration that both the brain stem and the cerebral functions are lost irreversibly.

In recent years, the number of organ donation and transplantation in our country has increased significantly. Although improvements have been made in the diagnosis and treatment processes of many diseases in the field of health, the definitive treatment method in many diseases resulting in organ failures is still organ transplantation. With the support of the Ministry of Health, important developments are taking place in our country regarding organ transplantation. In our country, kidney, liver, heart, cornea, lung, pancreas, extremities, and face transplant patients are increasing day by day. Today, the use of immunosuppressive drugs and the improvement of postoperative care conditions increase posttransplant survival rates and improve the patient's quality of life ${ }^{1}$.

Brain death is the irreversible loss of all brain functions. The concept of brain death was first described in 1959. The diagnosis of brain death has been standardized by establishing Harvard Criteria in $1968^{2}$. Brain death, and organ donation have become more important as a result of the developments in organ transplantation in the last 20 years because of the lack of adequate organs. There are two ways to procure the organ; procure of organs through live donors or cadavers. Although organ supply from living donors is a safe procedure, it is inevitable that a healthy person is at risk. Due to the lack of adequate cadavers, there is a search for organ from living. The supply of organ from cadavers is the most reliable source. At the same time, the heart, pancreas, lung, small intestine, and cornea are only available from the cadaver. Therefore, it is necessary to increase the number of cadavers from day to day. In countries, "brain death" has been defined by legal regulations, and important progress has been made in establishing an organ transplant pool. In Turkey, "Brain death and organ transplantation," What is that first legislation enacted in 1979, with the latest amendments made in 2012, this legislation has been adapted to world standards ${ }^{3}$. With "The Central Organ Transplant Coordination System" that is established by the Ministry of Health, the necessary communication has been established between "The Organ Transplant Region Coordinators," and important steps have been taken to expand both the donor pool and the delivery of the organs that patients need. The organ pool is inadequate to meet the needs around the world. For this reason, the number of donors is increased by the definition of "actual deceased donor after circulatory death: DCD” ${ }^{4,5}$. In Turkey also efforts are ongoing to increase the number of donors both in the works of central coordination centers and in the training and awareness of medical personnel in organ transplantation and brain death. 
In this study blood gas parameters before and after apnea test, demographic characteristics, educational status, duration of diagnosing brain death, distribution of the patients according to their services, organ donation rate, the causes of brain death were evaluated by assessing the records of the patients with brain death diagnosis between the dates of 01.01.2014-15.05.2019 in our hospital.

\section{MATERIAL AND METHODS}

After the approval of the Ethics Committee of Cumhuriyet University Non-Interventional Clinical Practices; The records of 44 patients who were diagnosed as brain death between 01.01.2014-15.05.2019 at Cumhuriyet University Research and Application Hospital were retrospectively reviewed. Blood gas parameters before and after apnea test which is a test that used in the diagnosis of brain death, demographic characteristics, educational status, duration of diagnosing brain death, distribution of the patients according to their services, organ donation rate, the causes of brain death were evaluated. In our study, the diagnosis of brain death was based on "brain death diagnostic criteria" and according to the current regulation in our country ${ }^{\text {six }}$ according to 2 expert physician evaluation (by the anesthesiologist or intensive care professional or neurosurgeon or neurologist); The brain death report is organized. After the brain death was confirmed, organ transplant coordinators of the hospital were interviewed by the family for organ donation.

Brain death committee in our hospital; under the most favorable conditions, in patients with coma and complete loss of brainstem reflexes as a sign of examination, they aim to perform a single-time and diagnostic apnea test in patients. Before the apnea test, the body temperature should be $\geq 36^{\circ}$ $\mathrm{C}$, blood pressure values should be above the normal lower limit for age, and medications that may affect the breathing effort should not be given to the patient. In the sample of arterial blood gas taken before the test, the $\mathrm{pH}$ and $\mathrm{PaCO} 2$ values are intended to be within normal limits, but In cases where hypercarbia related to COPD and similar lung pathologies cannot be corrected, at least $20 \mathrm{mmHg}$ increase rule is applied for the acceptance of apnea test as positive. Before starting the test, the patient is ventilated with $100 \%$ oxygen for 5-10 minutes. The patient should be de-connected from the mechanical ventilator after adequate oxygenation, and the intubation/tracheostomy tube provides 6-8 L / min oxygen to the carina level. During the test, the patient's spontaneous breathing effort is observed while on the other hand heart rate, blood pressure, and oxygen saturation are monitored continuously. $\mathrm{PaCO} 2$ measurement is performed in the arterial blood gas after 8 minutes after the patient was de-connected from the ventilator. If the patient's clinical condition is stable and the targeted $\mathrm{PaCO} 2$ values cannot be reached, blood gas samples are taken every 2 minutes by extending the test period. In such a case, when the target $\mathrm{PaCO} 2$ levels are reached, the test is terminated. For the apnea test to be interpreted as positive (consistent with brain death), $\mathrm{PaCO} 2$ should be $\geq 60 \mathrm{mmHg}$ at the end of the test, and there should not be any inhalation effort despite the increase of $\geq 20 \mathrm{mmHg}$ relative to baseline. In the case of any spontaneous breathing effort observed during the test, the test is not compatible with brain death (apnea test is negative) and is discontinued immediately. In the case of hemodynamic deterioration or hypoxemia during the apnea test, the test is terminated immediately. If the $\mathrm{PCO} 2$ criteria could not be met due to hemodynamic deterioration or any other reason, the apnea test is considered to be inconclusive (incomplete or uninterpretable). In this case, the apnea test should be repeated after the appropriate conditions are met. If the prerequisites of apnea test cannot be met or the test is terminated before reaching the target $\mathrm{PaCO} 2$ levels for various reasons, the declaration process is continued in our hospital by referring to supportive tests that evaluate cerebral blood circulation.

\section{Statistical analysis}

Frequency tables indicating the characteristics of the patients were prepared. The $\mathrm{pH}, \mathrm{pO} 2, \mathrm{pCO} 2$, HCO3 values were tested by the Shapiro-Wilk test. Arterial blood gas values before and after apnea test were tested with Wilcoxon signed rank test. At the same time, descriptive statistics were calculated by calculating the changes between the pre-post measurements in numerical and percentage terms. All tests were interpreted as a 95\% confidence level.

\section{RESULTS}

When the patients who were diagnosed with brain death in Cumhuriyet University Hospital between January 2014 and May 2019 were evaluated, 44 patients were found. Of these, 23 were female $(52.3 \%)$ and 21 were male $(47.7 \%)$. The education status of patients with brain death is shown in Table 1.

When the patients who were diagnosed with brain death were examined; 26 patients $(59.1 \%)$ were 
found to be in the neurosurgery intensive care unit and 13 patients $(29.5 \%)$ in anesthesia intensive care unit (Table 2). When the patients were examined, it was found that they were diagnosed as brain death at the mean length of $18.23 \pm 28.8$ days of hospitalization (minimum two days, maximum 157 days).

The mean age of patients with brain death was $45.32 \pm 24.75$ (minimum: 4 years, maximum: 87 years). When the patients diagnosed with brain death were examined, electrolyte disorder was detected in 17 patients, the metabolic disorder was detected in 2 patients, and brain death was diagnosed without cardiopulmonary resuscitation in 35 patients $(79.5 \%)$. Of the 44 patients diagnosed with brain death, $9(20.5 \%)$ were donors, and 35 (79.5\%) were non-donors. Family reasons are the most common cause of being nondonor (Table 3).

When the reasons leading to brain death are examined; The most common causes were subarachnoid hemorrhage (SAH) in 18 patients $(40.9 \%)$ and intraparenchymal cerebral hemorrhage in 14 patients (31.8\%) (Table 4).

Table 1: Educational Status of Patients with Brain Death

\begin{tabular}{|l|c|c|}
\hline Educational Status & Number of the patients & \% \\
\hline Not literacy & 11 & 25.0 \\
\hline Primary school & 12 & 27.3 \\
\hline Middle school & 6 & 13.6 \\
\hline High school & 10 & 22.7 \\
\hline University & 5 & 11.4 \\
\hline
\end{tabular}

Table 2: Distribution of Patients with Brain Death by Their Hospitalization Units

\begin{tabular}{|l|c|c|}
\hline Hospitalization Unit & Number of the patients & \% \\
\hline Neurosurgery ICU & 26 & 59.1 \\
\hline Anesthesiology ICU & 13 & 29.5 \\
\hline Neurology ICU & 2 & 4.5 \\
\hline Coronary ICU & 1 & 2.3 \\
\hline Pediatrics ICU & 2 & 4.5 \\
\hline
\end{tabular}

ICU: Intensive Care Unit

Table 3: Reasons for Patients with Brain Death Not Being Donors

\begin{tabular}{|l|c|c|}
\hline Reason for being non-donor & Number of the patients & \% \\
\hline Family reasons & 18 & 40.9 \\
\hline Religious reasons & 10 & 22.7 \\
\hline Because of the patient's will & 5 & 11.4 \\
\hline Ethic reasons & 2 & 4.5 \\
\hline
\end{tabular}

Table 4: The Frequency of The Causes of Brain Death

\begin{tabular}{|l|c|c|}
\hline The Causes of Brain Death & Number of the patients & \% \\
\hline Subarachnoid hemorrhage & 18 & 40.9 \\
\hline $\begin{array}{l}\text { Intraparenchymal brain } \\
\text { hemorrhage }\end{array}$ & 14 & 31.8 \\
\hline Intracranial mass & 6 & 13.6 \\
\hline Hypoxic ischemic encephalopathy & 2 & 4.5 \\
\hline Encephalitis & 1 & 2.3 \\
\hline Cerebral infarct & 1 & 2.3 \\
\hline Subdural hematoma & 1 & 2.3 \\
\hline Pulmonary thromboembolism & 1 & 2.3 \\
\hline
\end{tabular}


When the mean values of arterial blood gas parameters before and after apnea test were compared; After apnea test, an average of 0.19 decreases in ph value, an increase of $34.27 \mathrm{mmHg}$ in $\mathrm{pCO} 2$, a decrease of $55.21 \mathrm{mmHg}$ in $\mathrm{pO} 2$, and
$2.64 \mathrm{mmol} / \mathrm{L}$ in $\mathrm{HCO} 3$ were seen. The Changes in mean values of arterial blood gas parameters before and after the apnea test was found to be statistically significant and are shown in Table $\mathbf{5}$ $(\mathrm{p}<0.01)$.

Table 5: Mean values of arterial blood gas parameters before and after apnea test

\begin{tabular}{|l|c|c|c|}
\hline $\begin{array}{l}\text { Arterial blood gas } \\
\text { parameters }\end{array}$ & Before the Apnea test & After the Apnea test & p-value \\
\hline $\mathrm{ph}$ & $7.35 \pm 0.07$ & $7.15 \pm 0.08$ & $\mathrm{p}<0.01^{*}$ \\
\hline $\mathrm{pCO}(\mathrm{mmHg})$ & $41.96 \pm 5.64$ & $76.24 \pm 13.67$ & $\mathrm{p}<0.01^{*}$ \\
\hline $\mathrm{pO}_{2}(\mathrm{mmHg})$ & $233.31 \pm 63.19$ & $178.09 \pm 94.82$ & $\mathrm{p}<0.01^{*}$ \\
\hline $\mathrm{HCO}_{3}(\mathrm{mmol} / \mathrm{L})$ & $22.80 \pm 3.72$ & $25.44 \pm 4.55$ & $\mathrm{p}<0.01^{*}$ \\
\hline
\end{tabular}

*p $<0.05$ significant

\section{DISCUSSION}

In our study; In our hospital, between January 2014 and May 2019, 44 patients were diagnosed with brain death, the mean time between hospitalization and diagnosis of brain death was 18 days, and the rate of the family donation was $20.5 \%$.

Gender varies between countries in patients diagnosed with brain death. In our study, 52.3\% of patients diagnosed with brain death were female gender; studies conducted in our country reported that the majority of those diagnosed with brain death are male sex $7,8,9,10$. Aghighi et al. ${ }^{11}$ reported from Iran that the rate of brain death in males was 2.1 times that of females and Han et al. ${ }^{12}$ in a study conducted in South Korea; women were more diagnosed with brain death $(65 \%)$.

The most common hospitalization diagnoses leading to the brain death process are usually sudden bleeding and obstructive intracranial events ${ }^{13,14}$. Karasu et al. ${ }^{7}$ reported that 58 (73.4\%) of 79 patients with brain death were hospitalized with bleeding-obstructive cerebrovascular disease. De Eira et al. ${ }^{13}$ in a study conducted in Portugal, the most common cause of brain death was hemorrhagic (55.3\%) and ischemic (17.4\%) strokes. Escudero et al. ${ }^{14}$ also reported that the most common causes of their 1844 brain death cases were intracerebral hemorrhage, traumatic brain injury, subarachnoid hemorrhage, and stroke. When the causes of brain death in our study are examined; The most common causes were subarachnoid hemorrhage (SAH) in 18 patients (40.9\%) and intraparenchymal cerebral hemorrhage in 14 patients $(31.8 \%)$. When the patients diagnosed with brain death are examined according to their services; $59.1 \%$ of patients underwent neurosurgery intensive care, $29.5 \%$ of them underwent anesthesia intensive care.

Although brain death diagnosis is a clinically diagnosed diagnosis, the apnea test is performed with the detailed neurological examination and brain death is decided. However, when the neurological examination cannot be performed completely, and apnea testing is not appropriate, or if patients cannot tolerate apnea testing, supportive tests are performed to shorten the duration of the diagnosis ${ }^{14}$. In a study conducted in Spain, the country with the highest organ donation rate in the world, the rate of supporting testing was reported to be $95 \%{ }^{14}$. In this study conducted in Spain, electroencephalography (EEG) or transcranial Doppler ultrasonography (USG) was widely used since it was easy to perform at the bedside. In our study, CT angiography, a supportive test which could not be performed at the bedside after the apnea test, was preferred in all patients. In other words, the rate of CT angiography, which is a supportive test is $100 \%$ in cases with brain death in our hospital. We did not have a transcranial doppler USG device in our hospital, so we cannot use it in routine practice in the diagnosis of brain death. CT angiography was preferred due to the inability to fully evaluate the EEG result due to the interaction of the EEG device in use with electronic devices in intensive care units. Of the 44 patients diagnosed with brain death in our hospital, 35 (79.5\%) were diagnosed with brain death by neurological examination, apnea test, and auxiliary tests without cardiopulmonary resuscitation.

After the family interviews following the diagnosis of brain death, if the family responds positively to the organ donation, the decision of the patient to be a donor is taken. The rate of 
family donation in cases diagnosed with brain death varies according to the countries or even the cities in the same country. Karasu et al. ${ }^{7}$ reports that; Of the 79 patients diagnosed with brain death during a 7-year period in Bursa Yüksek İhtisas Training and Research Hospital, 27 (34.2\%) of the families gave consent to organ donation, Kiraklı et al. ${ }^{8}$ in a study conducted for past 2 years in Izmir Tepecik Education and Research Hospital in 48 out of 1759 patients were found to be diagnosed with brain death, and 33 patients (69\%) found that their relatives accept organ donation. Uludağ et al. ${ }^{9}$ reported that 59 patients were diagnosed with brain death between 2008 and 2014 in Adiyaman University Training and Research Hospital, and five patients $(8.7 \%)$ were donors. Han et al. ${ }^{12}$ examined 107 cases with brain death and found that the organ donation rate was $58 \%$ (n: 62). Karan et al. ${ }^{15}$; In a retrospective study of patients diagnosed with brain death at Uludağ University Hospital between January 2015 and December 2017, families of 20 patients (41.7\%) from 48 cases diagnosed with brain death responded favorably to organ donation. Batttal et al. ${ }^{16}$ found that among the 62 brain deaths detected in Okmeydanı Training and Research Hospital between September 2007 and January 2012, relatives of 18 (29\%) patients permitted to donate organs. In our study; Out of 44 patients diagnosed with brain death, $9(20.5 \%)$ were donors, and 35 (79.5\%) were non-donors.

In a study conducted in Spain, the country with the highest rate of donation in the world, 1291 (70\%) of the 1844 patients with brain death were donors, and only 244 patients (13.2\%) were not donors due to family refusal ${ }^{14}$. When we look at our country, we see that organ donation rates vary between regions. Between 2015-2017, a total of 6011 patients were diagnosed with brain death in our country. The family of 1589 patients responded positively to organ donation. All organ donation rate in Turkey in the last two years was found to be $26.43 \%$. In the Istanbul Regional Coordination Center, where important transplant centers and large organ pools are located, the donation rate is $27.7 \%$. This ratio is $22.1 \%$ in Ankara Regional Coordination Center. In our study, our hospital organ donation rate $(20.5 \%)$ were found to be lower than the average of Turkey. We think that this study is important because it is the first study that evaluated our hospital for brain death even though it includes single center data in Sivas province. Retrospective evaluation of 44 cases diagnosed as brain death within five years in the intensive care unit of our hospital revealed that organ donation rates were below the national average. We think that not delaying in donor determination, not to be lack of donor care, training of health workers in brain death and organ donation will increase the awareness on organ donation, and organ donation rates will increase in our hospital.

\section{REFERENCES}

1. Chudoba P, Krajewski W, Wojciechowska J, Kamińska D. Brain death-associated pathological events and therapeutic options. Adv Clin Exp Med 2017; 26: 1457-64.

2. Farrell MM. Levin DL. Brain death in the pediatric patient: historical, sociological medical, religious cultural legal, and ethical considerations. Crit Care Med 1993; 21(12): 1951-65.

3. https://www.saglik.gov.tr/TR,10528/organ -ve-doku-naklihizmetleri-yonetmeligi.html (the date of access: 07.03.2018).

4. Morrissey PE, Monaco AP. Donation after circulatory death: current practices, ongoing challenges, and potential improvements. Transplantation 2014; 15 : 258-64.

5. Manyalich M, Nelson H, Delmonico, FL. The need and opportunity for donation after circulatory death worldwide. Curr Opin Organ Transplant 2018; 23: 136-41.

6. http://www.mevzuat.gov.tr/MevzuatMetin/ 1.5.2238.pdf (the date of access: 04.08.2018)

7. Karasu D, Yılmaz C, Karaduman I, Çınar YS, Buyukkoyuncu Pekel N. Retrospective analysis of brain death cases. Yoğun Bakım Journal 2015; 6: 23-6.

8. Kıraklı C, Uçar ZZ, Anıl AB, Özbek İ. The effect of shortening the definitive diagnosis time on the organ donation rates in the intensive care unit, Yoğun Bakım Journal 2011; 1: 8-11.

9. Uludağ Ö, Sabuncu Ü, Kuşderci H, Kaplan F, Tutak A, Doğukan M. Where are we in organ donation? J Turk Soc Intensive Care 2016; 14: 86-92.

10. Yilmaz Ferhatoglu S, Yapici N. Brain Death and Organ Donation Rates in a City Hospital: A Retrospective Study. Cureus 2019; 11(2): 1-10.

11. Aghighi M, Mahdavi-Mazdeh M, Saberi Isfeedvajani $\mathrm{M}$, et al. Brain-dead donation rate in the month of Ramadan and the other months: 2005-2014. Int J Organ Transplant Med 2017; 8: 165-7. 
12. Han SY, Kim JI, Lee EW, et al. Factors associated with a family's delay of decision for organ donation after brain death. Ann Transplant 2017; 22: 17-23.

13. Eira CSLD, Barros MIT, Albuquerque AMP. Organ donation: the reality of an intensive care unit in Portugal. Rev Bras Ter Intensiva 2018; 30: 201-7.

14. Escudero D, Valentín MO, Escalante JL, et al. Intensive care practices in brain death diagnosis and organ donation. Anaesthesia 2015; 70: 1130-9.
15. Karan E, Elgin E, Oflaz R, Selimoğlu K, Coşkun B, Kelebek Girgin N. Retrospective analysis of organ donation rates in patients diagnosed with brain death in a university hospital. Uludağ University Medical School Journal 2019; 45 (1): 4146.

16. Battal M, Horoz A, Karatepe O, Çitgez B. Research hospital experience in brain death detection. Şişli Etfal Hospital Medical Bulletin 2013; 47(2): 59-62. 